\title{
Evaluation of progesterone and progesterone receptor gene PROGINS polymorphism in the development of some forms of premenstrual syndrome
}

\author{
L.V. Pakharenko \\ SHEE «Ivano-Frankivsk National Medical University» \\ The New Armenian Medical Journal, Vol.9 (2015), No 2, p. 52-59
}

One of the most common neuroendocrine syndromes in gynecology is premenstrual syndrome (PMS). The article is devoted to study of progesterone level and frequency of polymorphic variants T1T2 of progesterone receptor gene PROGINS, as well as their possible relationship in patients with various forms of PMS. The object of the study were 50 women of reproductive age with diagnosis of PMS, including 25 women with edematous form of the disease, 25 - with neuropsychical form. Mild form of disease had 25 women, severe form - also 25 persons. Control group consisted of 25 women without diagnosis of PMS. Progesterone level was determined in blood serum twice in the first and second phase of menstrual cycle. Polymorphism T1T2 of progesterone gene receptor PROGINS was studied using polymerase chain reaction.

We found hypoprogesteronemia of luteal phase of menstrual cycle in women with PMS, especially pronounced in persons with edematous and severe forms of the disease $(\mathrm{p}<0.05)$.

Polymorphic variant T1T2 of gene PROGINS can be considered as a marker of development of PMS. T1T1 genotype was significantly associated with development of edematous form $\left(\chi^{2}=4.50 ; p=0.03\right)$ and its presence may indicate a tendency to develop of severe form of PMS $\left(\chi^{2}=3.21 ; p=0.07\right)$. T2 allele can be considered as a protective mechanism for the appearance of PMS, particularly its edematous and severe forms, in which the presence of T2 allele reduces the risk of PMS, respectively 3.0 times $\left(\chi^{2}=4.50 ; p=0.03,0 R=0.2095 \%\right.$ CI $0.05-0.78$; $\mathrm{p}=0.02)$ and 1,71 times $\left(\chi^{2}=3.21, \mathrm{p}=0.07, \mathrm{OR}=0.27,95 \% \mathrm{CI} 0.08-0.95, \mathrm{p}=0.04\right)$ compared with control group.

Reduced blood level of progesterone in women with PMS correlated with the presence of T1T1 genotype of gene PROGINS. By edematous, neuropsychical, severe and mild forms of PMS and the presence of T1T1 genotype there were significantly low levels of this hormone in the second phase of menstrual cycle $(p<0.05)$ relative to women with the same genotype in the control group of. Furthermore, there was no statistically significant difference in progesterone level in women with T1T2 genotype in these groups compared with healthy women with same genotype (p>0.05).

Key words: premenstrual syndrome, progesterone, progesterone receptor gene PROGINS, polymorphism.

\section{Значение прогестерона и полиморфизма гена рецептора прогестерона PROGINS в развитии некоторых форм предменструального синдрома \\ Л.в. Пахаренко}

Одним из наиболее распространенных нейроэндокринных синдромов в гинекологии является предменструальный синдром (ПМС). Статья посвящена изучению уровня прогестерона и частоты полиморфных вариантов T1T2 гена рецептора прогестерона PROGINS, a также их возможной взаимосвязи у больных с различными формами ПМС. Объектом исследования были 50 женщин репродуктивного возраста с диагнозом ПМС, из них у 25 женщин диагностировано отечную форму заболевания, 25 - нейропсихическую. Легкое и тяжелое течение болезни отмечали у 25 женщин. В контрольную группу вошли 25 женщин без диагноза ПМС. Уровень прогестерона определяли в сыворотке крови дважды в I и II фазе менструального цикла. Полиморфизм T1T2 гена рецептора прогестерона PROGINS изучали с помощью полимеразной цепной реакции.

Была установлена гипопрогестеронемия лютеиновой фазы менструального цикла у женщин с ПМС, которая была особенно выражена при отечной и тяжелой формах заболевания $(\mathrm{p}<0,05)$.

Полиморфный вариант T1T2 гена PROGINS можно рассматривать как маркер развития ПМС. Генотип Т1T1 достоверно ассоциируется с развитием отечной формы заболевания $\left(\chi^{2}=4,50 ; \mathrm{p}=0,03\right)$, и его наличие может свидетельствовать о тенденции к развитию тяжелой формы ПМС $\left(\chi^{2}=3,21 ; \mathrm{p}=0,07\right)$. Аллель Т2 можно рассматривать как защитный механизм появления ПМС, а именно отечной и тяжелой форм болезни, при которых наличие Т2 аллеля уменьшает риск развития ПМС соответственно в 3,0 раза $\left(\chi^{2}=4,50 ; \mathrm{p}=0,03, \mathrm{OR}=0,20,95 \%\right.$ CI $0,05-0,78, \mathrm{p}=0,02)$ и 1,71 раза $\left(\chi^{2}=3,21 ; \mathrm{p}=0,07, \mathrm{OR}=0,27,95 \%\right.$ CI $\left.0,08-0,95, \mathrm{p}=0,04\right)$ по сравнению с контрольной группой.

Пониженный уровень прогестерона крови у женщин с ПМС коррелировал с наличием генотипа T1T1 гена PROGINS. У больных ПMC, которые имели генотип Т1T1, отмечено достоверно низкие показатели этого гормона во второй фазе менструального цикла $(\mathrm{p}<0,05)$ относительно уровня женщин контрольной группы с этим же генотипом. Кроме того, у женщин с данным нейроэндокринным синдромом и наличием генотипа Т1T2 достоверно значимых различий в уровне прогестерона по сравнению с показателями контрольной группы не было (р>0,05).

Ключевые слова: предменструальный синдром, прогестерон, ген рецептора прогестерона PROGINS, полиморфизм.

\section{Значення прогестерону і поліморфізму гена рецептора прогестерону PROGINS у розвитку деяких форм передменструального синдрому}

Л.В. Пахаренко

Одним із найбільш поширених нейроендокринних синдромів у гінекології є передменструальний синдром (ПМС). Стаття присвячена вивченню рівня прогестерону і частоти поліморфних варіантів T1T2 гена рецептора прогестерону PROGINS, а також їхнього можливого взаємозв'язку у хворих з різними формами ПМС. Об'єктом дослідження були 50 жінок репродуктивного віку з діагнозом ПМС, з них у 25 жінок діагностовано набряклу форму захворювання, у 25 - нейропсихічну. Легкий і тяжкий перебіг хвороби відзначали у 25 жінок. До контрольної групи увійшли 25 жінок без діагнозу ПМС. Рівень прогестерону визначали у сироватці крові двічі у I та II фазі менструального циклу. Поліморфізм Т1T2 гена рецептора прогестерону PROGINS вивчали за допомогою полімеразної ланцюгової реакції.

Була встановлена гіпопрогестеронемія лютеїнової фази менструального циклу у жінок з ПМС, яка була особливо виражена при набряклій і тяжкій формах захворювання $(\mathrm{p}<0,05)$. 
Поліморфний варіант T1T2 гена PROGINS можна розглядати як маркер розвитку ПМС. Генотип Т1Т1 достовірно асоціюється з розвитком набряклої форми захворювання $\left(\chi^{2}=4,50 ; \mathrm{p}=0,03\right)$, і його наявність може свідчити про тенденцію до розвитку тяжкої форми ПМС $\left(\chi^{2}=3,21 ; \mathrm{p}=0,07\right)$. Алель Т2 можна розглядати як захисний механізм появи ПМС, а саме набряклої та тяжкої форм хвороби, при яких наявність Т2 алеля зменшує ризик розвитку ПМС відповідно у 3,0 разу $\left(\chi^{2}=4,50 ; \mathrm{p}=0,03, \mathrm{OR}=0,20,95 \% \mathrm{CI} 0,05-0,78\right.$; $\left.\mathrm{p}=0,02\right)$ і в 1,71 разу $\left(\chi^{2}=3,21 ; \mathrm{p}=0,07, \mathrm{OR}=0,27,95 \%\right.$ CI 0,08-0,95; $\left.=0,04\right)$ порівняно з контрольною групою.

Знижений рівень прогестерону крові у жінок з ПМС корелював з наявністю генотипу T1T1 гена PROGINS. У пацієнток із ПМС, які мали генотип Т1T1, відзначено достовірно низькі показники цього гормону у другій фазі менструального циклу (р<0,05) щодо рівня жінок контрольної групи з цим же генотипом. Крім того, у жінок з цим нейроендокринним синдромом і наявністю генотипу Т1Т2 достовірно значущих відмінностей у рівні прогестерону порівняно з показниками контрольної групи не було (р>0,05).

Ключові слова: передменструальний синдром, прогестерон, ген рецептора прогестерону PROGINS, поліморфізм.

$\mathrm{P}_{\mathrm{n}}^{\mathrm{r}}$ remenstrual syndrome (PMS) is one of the most common neuroendocrine syndromes in gynecology. It affects mostly women of reproductive age age, regardless of their country of living [Direkvand-Moghadam A. et al., 2014]. More than 150 symptoms of physical and psychological nature may occur for 2-14 days before menstruation. This condition significantly disturbs lifestyle of women [Dennerstein L. et al., 2010; Choi D. et al., 2010]. In the development of PMS significant role belongs to reproductive hormones. Progesterone is a hormone of luteal phase of menstrual cycle. It is raised many questions about its role in development of this syndrome. Progesterone, and most likely its metabolites allopregnanolone and pregnanolone, have some importance in genesis of various symptoms of PMS in luteal phase (mood changes, metabolic disorders) [Ziomkiewicz A. et al., 2012; B ckstr m T. et al., 2014]. But the results of studies of its level in women with PMS are controversial. Scientists have found an increase [Lekareva T.M., 2007], decrease [Qiao M., 2008], and even a stable level of progesterone in luteal phase of menstrual cycle in women with this disease [Yakovleva E.B. et al., 2009; Ismailov S.I. et al., 2010].

Progesterone exerts its effects on cells through receptors A and B. Progesterone gene is located in chromosome 11q22-23. One of the polymorphic variants of gene of progesterone is gene PROGINS [Romano A. et al., 2007]. To date, the role of genetic factors in the development of gynecological pathology is not studied good. Is an open question about the meaning of gene PROGINS in development of breast cancer [Giacomazzi J. et al., 2012; Rockwell, 2012], genesis of recurrent abortion [Su MT et al., 2011; Traina E. et al., 2011]. PROGINS polymorphism of progesterone receptor may be associated with endometriosis and infertility on its background [Christofolini DM et al, 2011; Costa I.R. et al., 2011].

The contribution of genetic factors in pathogenesis of PMS is the least studied. In the study of polymorphism of S/L gene PROGINS of progesterone receptor was not found its role in the occurrence of this disease. Scientists believe that in the development of PMS certain meaning of combination of "increased functional activity of the corpus luteum in the second phase of menstrual cycle and presence of $\mathrm{L}$ allele of progesterone receptor gene PROGINS" takes place [Aganezova N.V., 2011].

The objective: to determine level of progesterone and frequency of polymorphic variants $\mathrm{T} 1 \mathrm{~T} 2$ of progesterone receptor gene PROGINS, as well as their possible relationship in patients with various forms of PMS.

\section{MATERIAL AND METHODS}

The clinical study was conducted on the basis of IvanoFrankivsk Clinical Maternity Hospital (Ivano-Frankivsk, Ukraine). Verification of diagnosis of PMS and severity of diseases (mild and severe) was performed according to the Order №676 of the Ministry of Health of Ukraine, 31.12.2004 [Ministry of Health, 2004]. Diagnosis of PMS was exhibited by presence of cyclical manifestations of the disease in luteal phase of menstrual cycle on the basis of history-taking and results of patient's selfobservation diary for 2-3 menstrual cycles (R. Moos Menstrual Distress Questionnaire). Form of the disease (edematous, neuropsychical) was determined according to V.P. Smetnik's classification [Smetnik V.P. et al., 1995]. We examined 50 women of reproductive age with diagnosis of PMS, which included basic group. Given that the most common forms of PMS are edematous and neuropsychical forms, basic group consisted of 25 women with edematous form of disease, 25 persons had neuropsychical form. 25 of them had mild PMS, 25 - severe form. Control group consisted of 25 women without diagnosis of PMS.

The criteria for inclusion of patients in research were: the reproductive age (18-44 years), regular menstrual cycles, presence of PMS, written consent of the patient. Exclusion criteria: women who had at the time of the study pregnancy or lactation, disorders of menstrual cycle, focal lesions of breast, dysfunctional uterine bleeding of unknown etiology, acute inflammation of pelvic organs, tumors of uterus and ovaries of unknown etiology, endometrial hyperplasia, genital endometriosis, severe somatic pathology in the history, organic pathology of the central nervous system, mental illness, hormonal tumors, diabetes, adrenal diseases, malignant tumors in the present or in anamnesis, premenstrual dysphoric disorder, women who took psychotropic medications or hormonal therapy within the last 3 months.

Progesterone level was determined in blood serum twice at $5-7$ th and 18-22d days of menstrual cycle by using immunofermental analysis with reagent set «Progesterone EIA» (XEMA Co., Ltd., Russia) and using analyzer «Stat Fax 303 Plus» (USA).

T1T2 polymorphism of the progesterone receptor gene PROGINS was studied in research laboratory, Department of

Progesterone levels in blood serum in obseved women, depending on the form of PMS, ng/mI

\begin{tabular}{|c|c|c|c|c|c|c|c|c|c|c|}
\hline \multirow{4}{*}{$\begin{array}{c}\text { Mark } \\
\text { Phase of cycle }\end{array}$} & \multicolumn{10}{|c|}{ Groups } \\
\hline & \multirow{2}{*}{\multicolumn{2}{|c|}{$\begin{array}{l}\text { Control group } \\
\qquad n=20\end{array}$}} & \multicolumn{8}{|c|}{ Basic group } \\
\hline & & & \multicolumn{2}{|c|}{$\begin{array}{l}\text { Edematous form of } \\
\text { PMS, } n=25\end{array}$} & \multicolumn{2}{|c|}{$\begin{array}{c}\text { Neuropsychical } \\
\text { form of PMS, } n=25\end{array}$} & \multicolumn{2}{|c|}{$\begin{array}{l}\text { Mild form of PMS, } \\
n=25\end{array}$} & \multicolumn{2}{|c|}{$\begin{array}{l}\text { Severe form of } \\
\text { PMS, } n=25\end{array}$} \\
\hline & 1 & II & $\mathrm{I}$ & II & 1 & II & 1 & II & 1 & II \\
\hline$M$ & 4.96 & 60.37 & 5.37 & 29.16 & 4.94 & 49.42 & 5.05 & 42.97 & 5.26 & 37.12 \\
\hline$\pm \mathrm{m}$ & 0.68 & 6.18 & 0.45 & 3.48 & 0.82 & 7.49 & 0.80 & 6.75 & 0.50 & 5.33 \\
\hline$p_{1}$ & & $<0.001$ & & $<0.001$ & & $<0.001$ & & $<0.001$ & & $<0.001$ \\
\hline $\mathrm{p}_{2}$ & & & & $<0.001$ & & 0.08 & & 0.02 & & 0.007 \\
\hline
\end{tabular}

Notes: $p_{1}$ - index of probability relative to index of I phase; $p_{2}$ - index of probability relative to index of control group. 
Medical Genetics, Shupyk National Medical Academy of Postgraduate Education. (Kiev, Ukraine). Material for the study was peripheral blood, which was collected into tubes with EDTA in amount $2.7 \mathrm{ml}$. Then DNA was isolated using a commercial set «DNA-sorb-B» (Institute of Epidemiology of the Ministry of Health of Russian Federation). Polymerase chain reaction was performed using the reagents of the company Fermentas (Lithuania) in thermocycler «FlexCycler» (Analytik Jena, Germany). DNA amplification products were separated according to their molecular weight by electrophoresis in $2 \%$ agarose gel with addition of ethidium bromide. Imaging was performed using a computer system Vitran.

For statistical analysis we used program Statistica 6.0. We calculated arithmetic mean value $(\mathrm{M})$, average standard deviation (m), significance of differences of research results $(\mathrm{p})$. To compare two independent groups by a single feature the nonparametric Mann-Whitney test was used, to compare two dependent groups

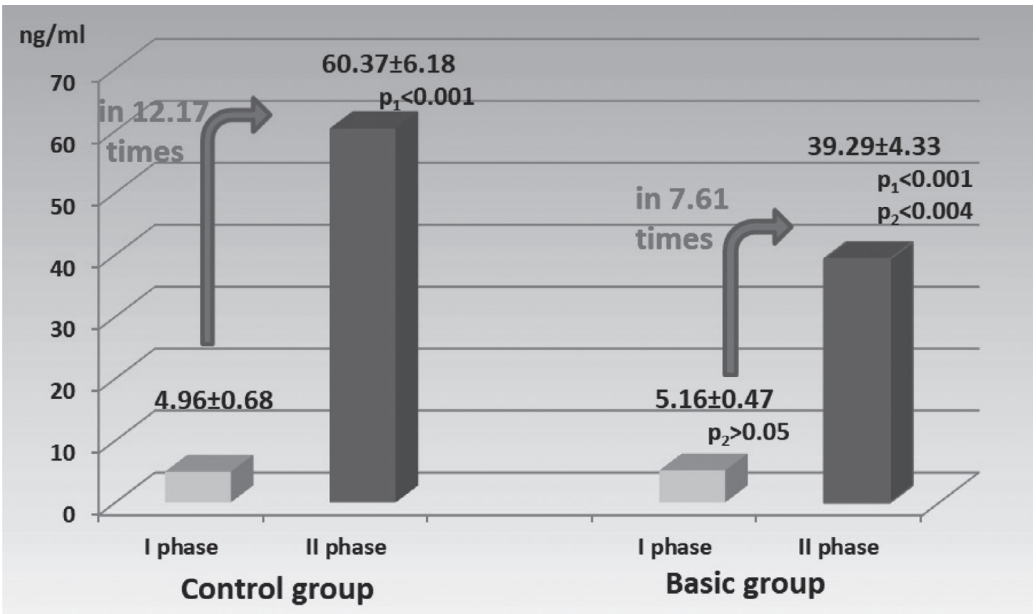

Fig. 1. Progesterone level in blood serum in observed women in two phases of menstrual cycle

Notes: $p_{1}$ - probability of difference of index of the second phase of menstrual cycle relative to the first one; $p_{2}$ - probability of difference of index relative to control group.

- Wilcoxon test. All calculations were carried out with reliable probability (1-P) 0.95 . We also used criterion $\chi^{2}$, odds ratio $(\mathrm{OR})$ and confidence interval (CI). The difference between the values that were compared were considered significant by $\mathrm{p}<0.05$.

\section{RESULTS AND DISCUSSION}

Progesterone levels in the follicular phase of menstrual cycle were similar in control $(4.96 \pm 0.68 \mathrm{ng} / \mathrm{ml})$ and basic groups $(5.16 \pm 0.47 \mathrm{ng} / \mathrm{ml})$. In both groups of patients we found a significant increase of progesterone in serum in II phase compared to I phase (see fig. 1). In controls its concentration increased in 12.17 times till $60.37 \pm 6.18 \mathrm{ng} / \mathrm{ml}(\mathrm{p}<0.001)$. Growth of progesterone in luteal phase in women with PMS was considerably lower than in healthy women - in 7.61 times till $39.29 \pm 4.33 \mathrm{ng} / \mathrm{ml}(\mathrm{p}$ $<0.001)$ and reached $65.08 \%$ of level in control group $(\mathrm{p}<0.004)$.

Concentration of progesterone in the I phase did not differ in women with various forms of PMS and consistent with the level of healthy women (table 1). The smallest increase of progesterone was observed in patients with edematous form of PMS - in 5.43 times till $29.16 \pm 3.48 \mathrm{ng} / \mathrm{ml}(\mathrm{p}<0.001)$, which accounted for only $48.30 \%$ of that of control group $(\mathrm{p}<0.001)$, and severe form of disease - in 7.06 times till $37.12 \pm 5.55 \mathrm{ng} / \mathrm{ml}$ and reached $61.49 \%$ of the level of healthy women $(\mathrm{p}<0.001)$. In patients with neuropsychical form progesterone increased in 10.00 times till $49.42 \pm 7.49 \mathrm{ng} / \mathrm{ml}(\mathrm{p}<0.001)$ and was $81.86 \%(\mathrm{p}=0.08)$ of the index of women in control group. Mild form of PMS characterized by increasing level of hormone in 8.51 times till $42.97 \pm 6.75 \mathrm{ng} /$ $\mathrm{ml}$ (71.18\% progesterone level of healthy persons).

Evaluation of results of distribution of polymorphic variants T1T2 of the progesterone receptor gene PROGINS showed that pathological variant T2T2 was quite rare in basic and control groups - in $2.0 \%$ of women with diagnosis of PMS and $8.0 \%$ without PMS (fig. 2).

T1T1 genotype was more common in 1.38 times in women with PMS (72.0\%) compared with healthy women $(52.0 \%)$. By analysis of the forms and severity of the disease it was determined a significant differences in spread of the genotypes among patients with edematous form of PMS and women in control group (table. 2). T1T1 genotype was determined in 1.61 times more among women with edematous form $\left(\chi^{2}=4,50 ; p=0.03\right)$, and in 1,54 times - with severe form $\left(\chi^{2}=3,21\right.$; $\mathrm{p}=0.07$ ) compared to healthy women (table 3 ).

Analyzing of distribution of T1T2 genotype tendency to more its spread in 1.54 times in women of control group (40.0\%) compared to basic group (26.0\%) was observed. In patients with

edematous and severe forms of PMS T1T2 genotype was set in 2.5 and 2.0 times less than that in healthy women $(\mathrm{p}>0.05)$.

Confirmation of meaning of T1T1 genotype in the development of PMS is the fact that the value of odds ratio by this disease in total (in basic group) and by its various forms and severity is greater than one $(1,39-4,85)$. And in patients with edematous and severe forms $« p »$ is less 0.05 relative to healthy women (table 4). This indicates to the association of T1T1 genotype of PROGINS gene with increased risk of PMS.

T1 allele was set most common in women in both groups. Frequency of its carriers among patients with PMS was $98.0 \%$ (49 patients), among healthy women - 92.0\% (23 women). And $100.0 \%$ of women with edematous and severe forms of neuroendocrine syndrome were carriers of this allele, with neuropsychical and mild forms of PMS - 96.0\% (24 patients).

We found that the allele T2 of gene PROGINS was determined among women of control group in 1.70 times more (12 women $-48.0 \%$ ) than among persons of basic group (14 patients $-28.0 \% ; \chi^{2}=2.13 ; \mathrm{p}=0.14, \mathrm{OR}=0.42,95 \%$ CI $0.16-1.14$; $\mathrm{p}=0.09$ ). T2 allele was set in 3.0 and 1.71 times less in patients with edematous and severe forms of PMS compared to con-

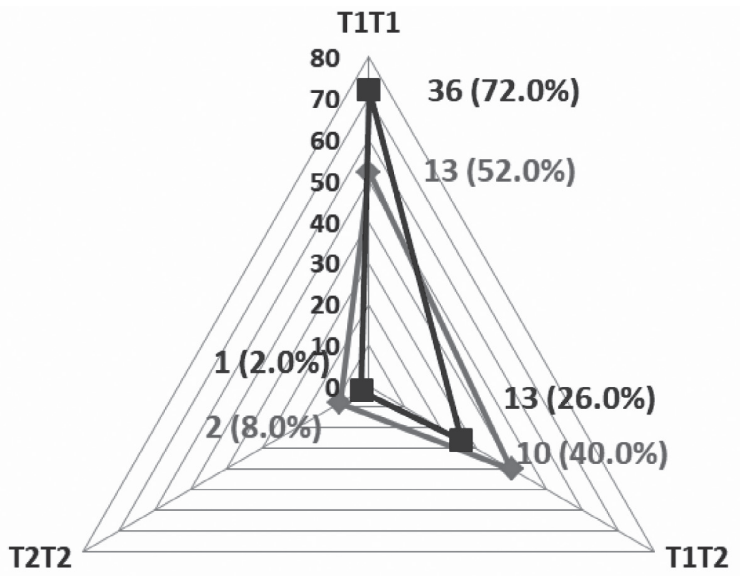

$\leadsto$ Control group $\rightarrow$ Basic group

Fig. 2. The frequency of polymorphic variants $T 1 T 2$ of the progesterone receptor gene PROGINS among observed women 
Frequency of T1T2 polymorphism of the progesterone receptor gene PROGINS among observed women

\begin{tabular}{|c|c|c|c|c|c|c|c|}
\hline \multirow{2}{*}{ Groups } & \multirow{2}{*}{$\mathbf{n}$} & \multicolumn{2}{|c|}{ T2T2 genotype } & \multicolumn{2}{c|}{ T1T2 genotype } & \multicolumn{2}{c|}{ T1T1 genotype } \\
\cline { 5 - 9 } & & Abs. & $\%$ & Abs. & $\%$ & Abs. & \% \\
\hline Control group & 25 & 2 & 8.0 & 10 & 40.0 & 13 & 52.0 \\
\hline Edematous form of PMS & 25 & - & - & 4 & 16.0 & 21 & 84.0 \\
\hline Neuropsychical form of PMS & 25 & 1 & 4.0 & 9 & 36.0 & 15 & 60.0 \\
\hline Mild form of PMS & 25 & 1 & 4.0 & 8 & 32.0 & 16 & 64.0 \\
\hline Severe form of PMS & 25 & - & - & 5 & 20.0 & 20 & 80.0 \\
\hline Basic group, total & 50 & 1 & 2.0 & 13 & 26.0 & 36 & 72.0 \\
\hline
\end{tabular}

Frequency of T1T2 polymorphism of the progesterone receptor gene PROGINS among observed women depending on form and severity of PMS compared with control group

\begin{tabular}{|c|c|c|c|c|c|c|c|c|c|c|}
\hline \multirow{2}{*}{ Groups } & \multirow{2}{*}{$\mathbf{n}$} & \multicolumn{3}{|c|}{ T2T2 genotype } & \multicolumn{3}{|c|}{ T1T2 genotype } & \multicolumn{3}{|c|}{ T1T1 genotype } \\
\hline & & $\%$ & $x^{2}$ & $p$ & $\%$ & $x^{2}$ & $p$ & $\%$ & $x^{2}$ & $p$ \\
\hline Control group & 25 & 8.0 & & & 40.0 & & & 52.0 & & \\
\hline Edematous form of PMS & 25 & - & - & - & 16.0 & 2.48 & 0.12 & 84.0 & 4.50 & 0.03 \\
\hline Neuropsychical form of PMS & 25 & 4.0 & 0.00 & 1.00 & 36.0 & 0.00 & 1.00 & 60.0 & 0.08 & 0.78 \\
\hline Mild form of PMS & 25 & 4.0 & 0.00 & 1.00 & 32.0 & 0.09 & 0.77 & 64.0 & 0.33 & 0.57 \\
\hline Severe form of PMS & 25 & - & - & - & 20.0 & 1.52 & 0.21 & 80.0 & 3.21 & 0.07 \\
\hline Basic group, total & 50 & 2.0 & 0.39 & 0.53 & 26.0 & 0.32 & 0.57 & 72.0 & 2.13 & 0.14 \\
\hline
\end{tabular}

Note: $p$ - probability of difference of index relative to control group.

trols - respectively in $16.0 \%\left(\chi^{2}=4.50 ; \mathrm{p}=0.03, \mathrm{OR}=0.2095 \%\right.$ CI $0.05-0.78 ; \mathrm{p}=0.02)$ and $20.0 \%\left(\chi^{2}=3.21 ; \mathrm{p}=0.07, \mathrm{OR}=0.27\right.$, $95 \%$ CI $0.08-0.95 ; \mathrm{p}=0.04)$. And in patients with neuropsychical form of the disease the number of carriers of T2 allele did not differ from the number of healthy women and reached $40.0 \%$ $\left(\chi^{2}=0.08 ; \mathrm{p}=0.77, \mathrm{OR}=0.72,95 \%\right.$ CI $\left.0.24-2.22 ; \mathrm{p}=0.57\right)$.

Such a statistical accuracy of $\mathrm{T} 2$ allele distribution in research groups may indicate of its importance in development of the disease as a protective element against the occurrence of PMS.

Then we tried to determine whether there is a relationship between progesterone blood level and form of genotype of gene PROGINS. By analyzing the results of research we found significant differences between the various genotypes T1/T2 of polymorphism progesterone PROGINS gene by various forms and levels of serum progesterone in luteal phase of menstrual cycle (table 5). Women in basic group with T1T1 genotype had progesterone concentration in luteal phase of menstrual cycle in 1.94 times lower than that of women with T1T1 genotype in control group $(\mathrm{p}<0.001)$, and which was accounted for $51.49 \%$ of control level. The lowest content of progesterone in examined persons with T1T1 genotype we found in women with edematous and severe forms of disease. By edematous form of PMS and presence of T1T1 genotype level of hormone was 2.34 times less $(\mathrm{p}<0.001)$, by severe form -2.04 times less $(\mathrm{p}=0.001)$, compared to healthy women with T1T1 genotype, and reached $42.69 \%$ and $49.06 \%$ of the controls' level. In persons with neuropsychical and mild forms of PMS and presence of T1T1 genotype significantly low level of progesterone, which corresponds respectively to $63.81 \%(\mathrm{p}=0,03)$ and $54.45 \%(\mathrm{p}=0,002)$ of level of controls with T1T1 genotype, was found.

In women with PMS who had T1T1 genotype the concentration of progesterone was lower on $19.37 \%$ than in carriers of T1T2 genotype. In particular, by edematous form of PMS progesterone level in persons with T1T1 genotype was on $9.44 \%$ lower than in persons with T1T2 genotype, by neuropsycical form - on $10.48 \%$, by severe PMS -

T1T2 genotypes of progesterone receptor gene PROGINS polymorphism as markers of the risk of PMS

Table 4

\begin{tabular}{|c|c|c|c|c|}
\hline Forms of PMS & Mark & T2T2 genotype & T1T2genotype & T1T1 genotype \\
\hline \multirow{3}{*}{ Edematous form } & OR & 0.18 & 0.29 & 4.85 \\
\hline & $\mathrm{Cl}$ & $0.01-4.04$ & $0.08-1,09$ & $1.29-18.26$ \\
\hline & $p$ & 0.28 & 0.07 & 0.02 \\
\hline \multirow{3}{*}{ Neuropsychical form } & OR & 0.48 & 0.84 & 1.39 \\
\hline & $\mathrm{Cl}$ & $0.04-5.65$ & $0.27-2.65$ & $0.45-4.25$ \\
\hline & $p$ & 0.56 & 0.77 & 0.57 \\
\hline \multirow{3}{*}{ Mild form } & OR & 0.48 & 0.71 & 1,64 \\
\hline & $\mathrm{Cl}$ & $0.04-5.65$ & $0.22-2.25$ & $0.53-5.09$ \\
\hline & $p$ & 0.56 & 0.56 & 0.39 \\
\hline \multirow{3}{*}{ Severe form } & OR & 0.18 & 0.38 & 3.69 \\
\hline & $\mathrm{Cl}$ & $0.01-4.04$ & $0.11-1.30$ & $1.05-12.96$ \\
\hline & $\mathrm{p}$ & 0.28 & 0.13 & 0.04 \\
\hline \multirow{3}{*}{ Basic group, total } & OR & 0.23 & 0.53 & 2.37 \\
\hline & $\mathrm{Cl}$ & $0.02-2.72$ & $0.19-1.46$ & $0.87-6.44$ \\
\hline & $p$ & 0.25 & 0.22 & 0.09 \\
\hline
\end{tabular}


Progesterone levels of observed women in luteal phase of menstrual cycle depending on T1/T2 polymorphism of progesterone receptor gene PROGINS, $\mathrm{ng} / \mathrm{ml}$

\begin{tabular}{|c|c|c|c|c|c|c|}
\hline \multirow{2}{*}{ Groups } & \multicolumn{2}{|c|}{ T1T1 genotype } & \multicolumn{2}{|r|}{ T1T2 genotype } & \multicolumn{2}{|c|}{ T2T2 genotype } \\
\hline & $n$ & $M \pm m$ & $n$ & $M \pm m$ & $n$ & $M \pm m$ \\
\hline Control group & 11 & $67.18 \pm 4.59$ & 7 & $56.11 \pm 13.95$ & 2 & $37.75 \pm 34.55$ \\
\hline Edematous form of PMS & 21 & $28.68 \pm 4.05 p<0.001$ & 4 & $31.67 \pm 5.26 p=0.26$ & - & - \\
\hline Neuropsychical form of PMS & 15 & $42.87 \pm 7.10 p=0.03$ & 9 & $\begin{array}{c}47.89 \pm 11.70 \\
p=0.71\end{array}$ & 1 & 161.30 \\
\hline Mild form of PMS & 16 & $\begin{array}{c}36.58 \pm 5.45 \\
p=0.002\end{array}$ & 8 & $\begin{array}{c}40.95 \pm 9.89 \\
p=0.42\end{array}$ & 1 & 161.30 \\
\hline Severe form of PMS & 20 & $32.96 \pm 5.46 p=0.001$ & 5 & $53.74 \pm 14.13 p=0.68$ & - & - \\
\hline Basic group, total & 36 & $34.59 \pm 3.91 p<0.001$ & 13 & $42.90 \pm 8.37 p=0.45$ & 1 & 161.30 \\
\hline
\end{tabular}

$38.67 \%$. In healthy women with T1T1 genotype level of progesterone was, conversely, more than in healthy persons with T1T2 or T2T2 genotypes. Furthermore, there was no statistically significant difference in progesterone level in women with T1T2 genotype in groups of edematous, neuropsychical, mild and sever PMS compared with healthy women with T1T2 genotype $(\mathrm{p}>0.05)$.

\section{CONCLUSIONS}

Identified changes point to a deep and complex nature of PMS, which are specific to each form of the disease. PMS is characterized by hypoprogesteronaemy in luteal phase of menstrual cycle, especially pronounced in edematous and severe forms of the disease $(\mathrm{p}<0.05)$.

Polymorphic variant T1T2 of gene PROGINS can be considered as a marker of development of PMS. T1T1 genotype was set in 1.61 times more among women with edematous form $\left(\chi^{2}=4.50\right.$; $\mathrm{p}=0.03, \mathrm{OR}=4.85,95 \%$ CI $1.29-18.26 ; \mathrm{p}=0.02)$, with severe 1.54 times more $\left(\chi^{2}=3.21 ; \mathrm{p}=0.07, \mathrm{OR}=3.69,95 \%\right.$ CI $1.05-12.96$; $\mathrm{p}=0.04)$ compared to control group. Thus, T1T1 genotype was significantly associated with the development of edematous forms of the disease and its presence may indicate a tendency to develop severe form of PMS.

$\mathrm{T} 2$ allele can be considered as a protective mechanism for the appearance of PMS, particularly its edematous and severe forms, in which the presence of T2 allele reduces the risk of PMS, respectively 3.0 times $\left(\chi^{2}=4.50 ; \mathrm{p}=0.03\right.$, OR=0.20 95\% CI $0.05-$ $0.78 ; \mathrm{p}=0.02)$ and 1.71 times $\left(\chi^{2}=3.21 ; \mathrm{p}=0.07, \mathrm{OR}=0.27,95 \% \mathrm{CI}\right.$ $0.08-0.95 ; \mathrm{p}=0.04$ ) compared with control group.

Reduced blood level of progesterone in women with PMS correlated with the presence of T1T1 genotype of gene PROGINS. By edematous, neuropsychical, severe and mild forms of PMS and the presence of T1T1 genotype there was significantly low levels of this hormone in the second phase of menstrual cycle $(\mathrm{p}<0.05)$ relative to women with the same genotype in control group. Furthermore, there was no statistically significant difference in progesterone level in women with T1T2 genotype in these groups of PMS compared to women with T1t2 genotype in control group $(\mathrm{p}>0.05)$.

\section{Сведения об авторе}

Пахаренко Людмила Владимировна - ГВУЗ «Ивано-Франковский национальный медицинский университет», 76018, г. Ивано-Франковск, ул. Галицкая, 2; тел.: (097) 430-69-21. E-mail: ludapak@rambler.ru

\section{REFERENCES}

1. Aganezova N.V. [The role of genetic and hormonal factors in the development of premenstrual syndrome] [Article in Russian]. Journal of Obstetrics and women's diseases 2011; LX, Issue 1: 1220.

2. Bäckström T., Bixo M., Johansson M., Nyberg S., Ossewaarde L., Ragagnin G. et al. Allopregnanolone and mood disorders. Prog Neurobiol. 2014; 113: 88-94.

3. Choi D., Lee D.Y., Lehert P., Lee I.S., Kim S.H., Dennerstein L. The impact of premenstrual symptoms on activities of daily life in Korean women. J Psychosom Obstet Gynaecol. 2010; 31 (1): 10-5.

4. Christofolini D.M., Vilarino F.L., Mafra F.A., André G.M., Bianco B., Barbosa C. P. Combination of polymorphisms in luteinizing hormone $\beta$, estrogen receptor $\beta$ and progesterone receptor and susceptibility to infertility and endometriosis. Eur J Obstet Gynecol Reprod Biol 2011; 158 (2): 260-4.

5. Costa I.R., Silva R.C., Frare A.B., Silva C.T., Bordin B.M., Souza S.R. et al. Polymorphism of the progesterone receptor gene associated with endometriosis in patients from Goiás, Brazil. Genet Mol Res 2011; 10 (3): 1364-70.

6. Dennerstein L., Lehert P., Keung L.S., Pal S.A., Choi D. Asian study of effects of premenstrual symptoms on activities of daily life. Menopause Int. 2010; 16 (4): 146-51.

7. Direkvand-Moghadam A., Sayehmiri K., Delpisheh A., Kakhavandi Sattar. Epidemiology of Premenstrual Syndrome (PMS) - A Systematic Review and MetaAnalysis Study. J Clin Diagn Res 2014; 8 (2): 106-9.

8. Giacomazzi J., Aguiar E., Palmero E.I., Schmidt A.V., Skonieski G., Filho D.D. et al. Prevalence of ERa-397 Pvull C/T, ERa-351 Xbal A/G and PGR PROGINS polymorphisms in Brazilian breast cancerunaffected women. Braz J Med Biol Res 2012; 45 (10): 891-7.

9. Ismailov S.I., Khaidarova F.A., Khodjaeva N.V., Guleva A.A. [Hypothalamic-pituitary-adrenal axis in the pathogenesis of premenstrual syndrome] [Article in Russian]. International Journal of Endocrinology 2010; 5 (29): 60-3.
10. Lekareva T.M. [Role of sex steroid hormones and prolactin in the pathogenesis of premenstrual syndrome] [Article in Russian]. Journal of Obstetrics and women's diseases 2007; 3: 100-6.

11. Ministry of Health of Ukraine. Order № $676,31.12 .2004$ «On approval of clinical protocols for obstetric and gynecological care» [In Ukraine].

12. Qiao M., Zhang H., Yu Y., Ci Y. Xu X., Ye Q. et al. Dynamic changes in serum estradiol and progesterone levels in patients of premenstrual syndrome with adverse flow of liver-qi. J Tradit Chin Med. 2008; 28 (2):106-9.

13. Rockwell L.C., Rowe E.J., Arnson K., Jackson F., Froment A., Ndumbe P. et al. Worldwide distribution of allelic variation at the progesterone receptor locus and the incidence of female reproductive cancers. Am J Hum Biol 2012; 24 (1): 42-51.

14. Romano A., Delvoux B., Fischer D.C., Groothuis $P$. The PROGINS polymorphism of the human progesterone receptor diminishes the response to progesterone. Journal of Molecular Endocrinology 2007; 38: 331-50.
15. Smetnik V.P., Tymilovich L.G. Non-operative Gynecology: A Guide for Physicians. Book 1 [In Rissian]. St. Petersburg .: Sothis; 1995, p. 129-38. 16. Su M.T., Lee I.W., Chen Y.C., Kuo P.L. Association of progesterone receptor polymorphism with idiopathic recurrent pregnancy loss in Taiwanese Han population. J Assist Reprod. Genet 2011; 28 (3): 239-43. 17. Traina E., Daher S., Moron A.F., Sun S.Y., Franchim C.S., Mattar R. Polymorphisms in VEGF, progesterone receptor and IL-1 receptor genes in women with recurrent spontaneous abortion. $\mathrm{J}$ Reprod Immunol 2011; 88 (1): 53-7.

18. Yakovleva E.B., Loskutova O.V. [Peculiarities of hormonal levels in adolescents with premenstrual syndrome] [Article in Russian]. International Journal of Endocrinology 2009; 1 (19): 86-8.

19. Ziomkiewicz A., Pawlowski B., Ellison P.T., Lipson S.F., Thune I., Jasienska $\mathrm{G}$. Higher luteal progesterone is associated with low levels of premenstrual aggressive behavior and fatigue. Biol Psychol. 2012; 91 (3): 376-82. 